\title{
Impact of air pollutants on some building materials in Cairo atmosphere
}

\begin{abstract}
Damage of materials is one of the most important adverse effects of air pollutants. The present investigation was undertaken to identify the extent of damage caused to some building materials by air pollutants in Cairo atmosphere and to what extent the pollutants accelerate the "natural" corrosion of materials. Samples of six different types of building materials (limestone, sand-lime brick, neat cement samples, cement blocks, industrial gypsum samples and LECA samples) were exposed to the ambient atmosphere for a period of three successive years at five locations, having different loads of air pollution represent residential and industrial areas through Cairo City. The changes in physical and chemical properties of the exposed materials were determined. It was found that the deterioration of building materials, exposed to Cairo city, was high related to the atmospheric pollution load with reference to sulfate, chloride and nitrate concentrations. Higher correlation coefficients between the compressive strength losses and the atmospheric $\mathrm{SO}_{2}$ and $\mathrm{NO}_{2}$ doses were found for cement block and limestone samples. The mineralogical composition (X-ray diffraction) of the product films of the exposed building materials showed the formation of gypsum and hydrated calcium silicate components in the building materials and cement content.
\end{abstract}

Volume 5 Issue 2 - 202I

\author{
Inas A Saleh,' Soliman AS El-Hemaly, ${ }^{2}$ Atef \\ MF Mohammed' \\ 'Air Pollution Research Department, Environmental Research \\ Division, National Research Centre, Egypt \\ ${ }^{2}$ Refractories, Ceramics \& Building Materials Department, \\ Inorganic Chemical Industries and Mineral Resources Research \\ division, National Research Centre, Egypt
}

Correspondence: Atef MF Mohammed, Air Pollution Research Department, Environmental Research Division, National Research Centre, Giza, Egypt, Fax +20 2 3337093 I, Tel +20 23337 I362, Mobile +20II5II 43456 Email ateffathy2006@yahoo.com

Received: April 06, 202I | Published: April 23, 202

Keywords: air pollution, gaseous pollutants, particulate matter, deterioration, building materials

\section{Introduction}

Gaseous and particulate air pollutants are significantly affect non-biological materials. Of particular importance are effects on building stones, historic and cultural monuments, which create an important part of our cultural heritage..$^{1-3}$ The effect of the deposition of atmospheric gases and aerosols on building materials constitutes one of the main damage mechanisms threatening the cultural heritage. Physical changes and chemical interaction occur at the building surface when exposed to outdoor atmosphere. The action of chemicals usually results in irreversible changes. Consequently, chemical damage to materials is of more serious problem. ${ }^{3,4}$ Dry deposition of gases plays an important role for the deterioration of stone materials. The dry deposition of gaseous air pollutants on stone and other materials is influenced by atmospheric processes and the chemical characteristics of the deposited gas species and of the specific receptor materials. ${ }^{5-7}$ The absorbed gases may act directly on the material, or first be converted to new substances that are responsible for observed effects. Gaseous pollutants such as sulfur dioxide and nitrogen oxides can react directly with the stone surface by forming acids in the presence of water (or moisture) and oxidizing agents. The formed acids react with the stone to form salts which either crystallize out within the stonework resulting in physical damage or they are washed away resulting in a loss of material. ${ }^{8-10}$ Sulfurous or sulfuric acids are capable of attacking a wide variety of building materials, including limestone, sandstone, concrete, marble, roofing slate, mortar, etc. Fairly soluble sulfates are formed, which are then leached away by rain. ${ }^{11,12}$
In Egypt, which is a repository for many buildings of history, museums and monuments, no previously serious study on air pollutants-induced damage on building materials could be traced. The cultural treasures are irreplaceable, so their preservation from the destructive effects of airborne contaminants poses a significant challenge to their present conservators. The aim of this work is to identify the environmental damage caused to some building materials by air pollutants in Cairo atmosphere and to assess to which extent urban and industrial atmosphere affect and accelerate the "natural" corrosion of materials. The study of environmental damage on stones and building materials is of fundamental importance in both the preservation of modern buildings and corrects planning of conservation works on historical monuments, in which such materials are commonly used.

\section{Materials and methods}

\section{Exposure of building materials to Cairo atmosphere}

Samples of six different types of building materials were exposed to the outdoor atmosphere at five locations, having different loads of air pollution represent residential and industrial areas throughout Cairo City. The chosen sites were:

I. Site 1: is a residential area north east of Cairo city with low population.

II. Site 2: is a residential area north west of Cairo with moderate population. 
III. Site 3: is a residential area south east of Cairo with moderate population.

IV. Site 4: is a residential industrial district south east of Cairo with moderate population, low traffic density and adjacent to industrial activities.

V. Site 5: is a heavy industrial sector southern of Cairo (El-Tebeen).

\section{The tested building materials}

The building materials that were investigated are:

A. Limestone: it is a natural rock and composed mainly of calcium carbonate.

B. Sand-lime brick: it is calcium silicate bricks, are manufactured by mixing $90 \%$ sand and $10 \%$ lime in the presence of water, molding and curing in an autoclave at about $170^{\circ} \mathrm{C}$. It is highly suitable for modular construction especially with panel units.

C. Neat cement samples: prepared from (Ordinary Portland) cement, which are mainly calcium silicates and mixed with $25 \%$ water. The paste was casted and cured under water for at least 28 days followed by drying.

D. Cement blocks: (10-15\%) cement and $85-90 \%$ mixture from sand $(30 \%)$ and limestone aggregates $(70 \%)$ with water (35$40 \%$ ), molded and cured at room temperature for $24 \mathrm{~h}$.

E. Industrial gypsum samples: namely Plaster of Paris, were prepared by mixing gypsum with water $(25 \%)$, moulded in one inch cubes, cured for 3 days under normal conditions and subjected to dryness in oven at $50^{\circ} \mathrm{C}$ for 24 hours.

F. LECA samples: (lightweight expanded clay aggregates) are manufactured from a special type of clay containing certain percentage of organic material and conforming to controlled chemical coefficient such as $\mathrm{Al} / \mathrm{Si}$ ratio, alkali and iron contents.

Generally, these stones and building units are widely used in buildings and as constituents of archaeological religious artifacts and historical monuments.

\section{Preparation and exposure of samples to outdoor atmosphere}

The stone and building unit samples were cut (or moulded) as cubes of approximate dimensions of $(3 \times 3 \times 3 \mathrm{~cm})$ and mounted on wooden tables placed over roofs of buildings in the selected sites. All stone and building unit samples were exposed to the atmosphere for a period of successive three years. Five samples of each type were removed from each site after exposure of one, two and three years interval and were taken off to the laboratory for the measurements.

\section{Mechanical test}

Mechanical testing of building stones offers possibilities of measuring the atmospheric deterioration of buildings. Mechanical test was determined from the compressive strength measurements. ${ }^{13,14}$ Compressive strength measurement was conducted by using a universal-testing machine (VED Werkstoff pruf maschiner Leipzing M/C.S No. 1316062, Fabr. Nr.264/37, Scales 0-60/40/ 20 tons). Three samples (of dimensions $3 \times 3 \times 3 \mathrm{~cm}$ ) were tested for each type after all the exposure intervals. Control samples were also examined and the change in compressive strength due to the exposure to the atmosphere at the different chosen locations was recorded. The reported results are the average for three samples and expressed as $\mathrm{kg} / \mathrm{cm}^{2}$.

\section{The mineralogical composition of building materials (X-ray Diffraction)}

The product films constituents of the investigated building samples, exposed at residential and industrial districts for a period of three years, were examined by $\mathrm{X}$-ray diffraction analysis and compared with the control samples. The product film of the top surface of each type of building samples were ground and packed in a plastic holder; no adhesive or binder was added. X-ray powder patterns were obtained at room temperature using a Philips diffractometer (Type pw 1399) employing Ni-filtered CuK $\alpha$-radiation $(\lambda=1.5404 \AA)$. The $\mathrm{X}$-ray tube was operated at $36 \mathrm{Kv}$ and $25 \mathrm{~mA}$. The diffraction angle $2 \theta$ was scanned at a rate of 2 degrees. $\mathrm{min}^{-1}$.

\section{Air pollution measurements}

Atmospheric pollutants in both forms (particulates and gases) were measured with the exposure of materials. Daily (24 hours) measurements of sulfur dioxide, nitrogen dioxide and suspended particulate matter were monitored at the same selected sites in Cairo city. West and Geak method was applied for the determination of sulfur dioxide. ${ }^{15}$ Nitrogen dioxide was measured according modified Saltzman technique. ${ }^{16}$ Suspended particulate matters was measured depends on the filtration technique. Vacuum pump with rate of 10liter/ minute and membrane filter paper $(<10 \mu \mathrm{m})$ were used for collecting the suspended particulate matters. Deposited particulate matter was also detected at the selected sites. Deposited dust collectors were used for collecting dust deposited from the ambient air of investigated sites. The collectors consist of cylindrical glass beakers $17 \mathrm{~cm}$ in height and $8-9.5 \mathrm{~cm}$ diameter. The cylindrical glass beaker was half filled with distilled water to avoid re-entrainment of the collected dust and mounted on iron tripods at a height of $1.2 \mathrm{~m}$ above roof level to avoid the collection of surface dust and placed between at least $2.4-15 \mathrm{~m}$ above ground level. ${ }^{17,18}$ Sulfates, chlorides and nitrates were determined in the water-soluble portion of both suspended and deposited particulate matter by using ion chromatography. Statistical analysis of data included determination of arithmetic mean \pm S.D. For studying as association between two variables, correlation coefficient (r) was used. ${ }^{19,20}$

\section{Results and discussion}

\section{Variation in the mechanical characteristics of building materials (compressive strength)}

Figures $1 \mathrm{~A}-1 \mathrm{~F}$ show the average compressive strength of the chosen building units exposed at the various districts in Cairo after successive three years of exposure. The figures clearly indicate that the compressive strength for all the examined building materials were decreased at all the districts compared with the control one. This is mainly due to the external effects and internal weakness in building stones, due to the action of air pollutants, and the formation of imbrittlement crusts at the surfaces of stones. As it has been expected, the lowest deterioration, in turn of compressive strength were recorded for building samples exposed to the atmosphere of the pure residential area with low population and low human activities (site 1). This is not surprising, since from pollution results of this study, the atmosphere of site (1) have a relatively low pollution load compared to those of other districts of Cairo City (Table 1). On the other hand, the highest deterioration was recorded at site 5 (industrial area) for all the examined samples where high concentrations of gaseous and particulate pollutants are emitted due to the industrial activities. 


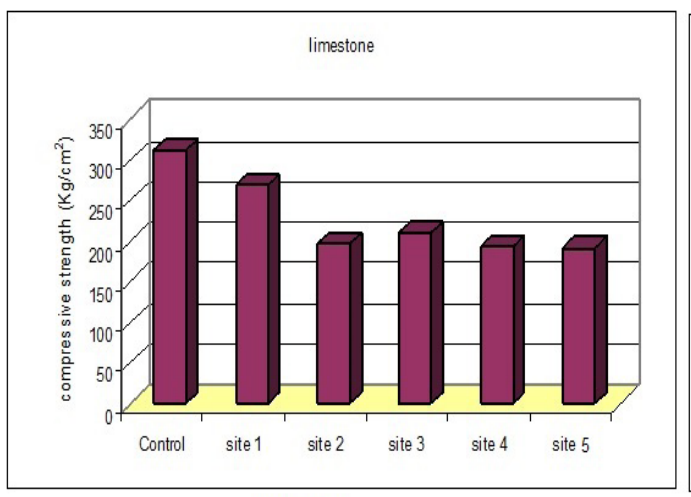

Fig. (A)

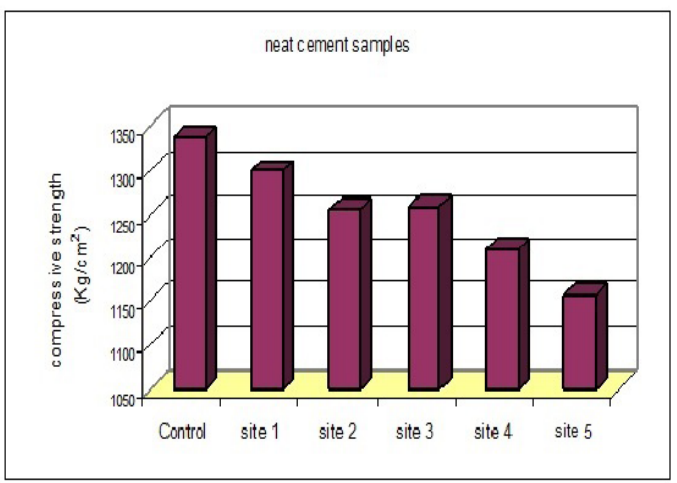

Fig. (C)

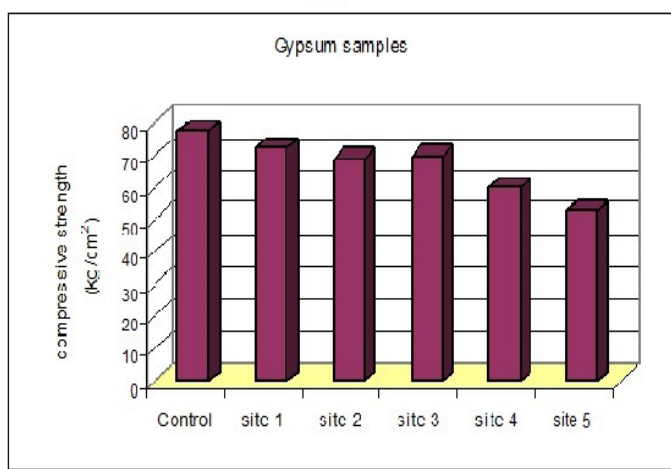

Fig. (E)

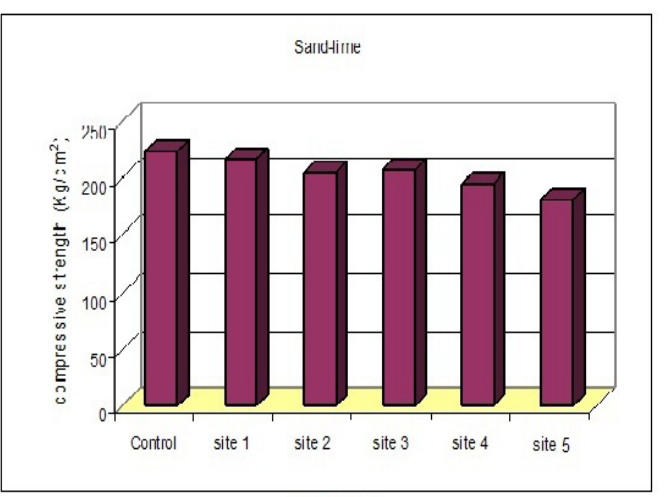

Fig. (B)

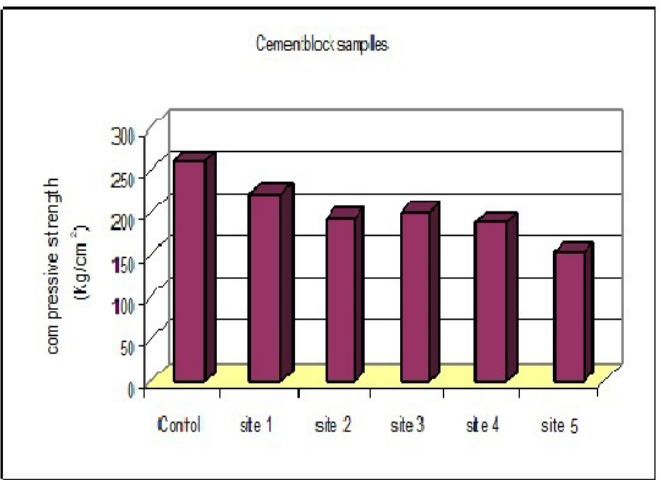

Fig. (D)

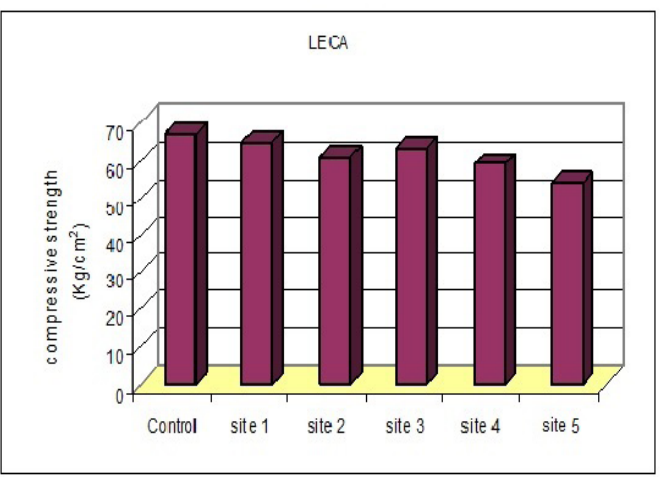

Fig. (F)

Figure I The average compressive strength of building units exposed at the various sites in Cairo City for a period of three years.

Table I Annual mean concentrations of air pollutants at the different investigated sites

\begin{tabular}{lllllll}
\hline Pollutants & & Site I & Site 2 & Site 3 & Site 4 & Site 5 \\
\hline $\mathrm{SO}_{2}\left(\mathrm{ug} / \mathrm{m}^{3}\right)$ & & 21.63 & 71.65 & 46.90 & 22.22 & 120.68 \\
$\mathrm{NO}_{2}\left(\mathrm{ug} / \mathrm{m}^{3}\right)$ & & 56.52 & 110.63 & 82.75 & 93.98 & 227.21 \\
& Sulfates & 17.58 & 24.56 & 26.80 & 37.66 & 77.49 \\
\multirow{2}{*}{ Deposited } & Chlorides & 3.44 & 6.00 & 6.74 & 15.41 & 22.94 \\
& Nitrates & 2.12 & 1.69 & 1.85 & 1.80 & 2.79 \\
& Sulfates & 20.02 & 34.97 & 40.17 & 48.86 & 76.60 \\
\multirow{2}{*}{ Suspended } & Chlorides & 5.26 & 7.11 & 11.54 & 18.68 & 49.74 \\
& Nitrates & 5.03 & 4.49 & 5.22 & 5.21 & 8.10 \\
\hline
\end{tabular}

Deposited salts expressed as $\mathrm{mg} / \mathrm{m}^{2}$.day; Suspended salts expressed as $\mu \mathrm{g} / \mathrm{m}^{3}$ 
The lower compressive strength for limestone samples was $193 \mathrm{~kg} /$ $\mathrm{cm}^{2}$ (exposed at site 5) compared to $313 \mathrm{~kg} / \mathrm{cm}^{2}$ for the control samples (Figure 1A). This means that the compressive strength was decreased by about $38.3 \%$ of its original value at this site after three years of exposure (Figure 2). Meanwhile, at site 1 it reached $280 \mathrm{~kg} / \mathrm{cm}_{2}$, i.e., it lost $10.5 \%$ of its blank reading. This higher loss in compressive strength at the industrial area of site 5 is mainly due to that this area has received the highest rate of particulates precipitation, especially sulfates, and $\mathrm{SO}_{2}$ concentrations which are highly destructive to limestone. These results are confirmed by ${ }^{21,22,23}$ who stated that "In the presence of $\mathrm{SO}_{2}$ and acidic compounds, carbonate building stone, calcite $\left(\mathrm{CaCO}_{3}\right)$, reacts to form $\mathrm{CaSO}_{3} \cdot 2 \mathrm{H}_{2} \mathrm{O}$ and $\mathrm{CaSO}_{4} \cdot 2 \mathrm{H}_{2} \mathrm{O}$ (gypsum), which are highly susceptible to surface erosion". Also, gypsum has a larger volume than calcite, which results in tension and possible fractures..$^{1-3}$ In Cairo atmosphere due to the lack of rain, gypsum is probably not dissolved and instead it deposited and forms a surface layer on the stone, which may eventually crack and peel off causing the higher loss in compressive strength. The significant deterioration in the strength of samples at site 5 can be also attributed to the presence of high rate of chloride precipitation from the industrial activities which lead also to attacking the building limestone. This is confirmed by the results of. ${ }^{6,24-26}$ The erosion effects are not limited to the surface, as acidic pollutants can penetrate into the interior through the pore structure of the stone leading to a further decrease in compressive strength.

\section{$\square$ limestone $\square$ sand-lime $\square$ neat cement $\square$ cement block 圆 gypsum 图 LECA}

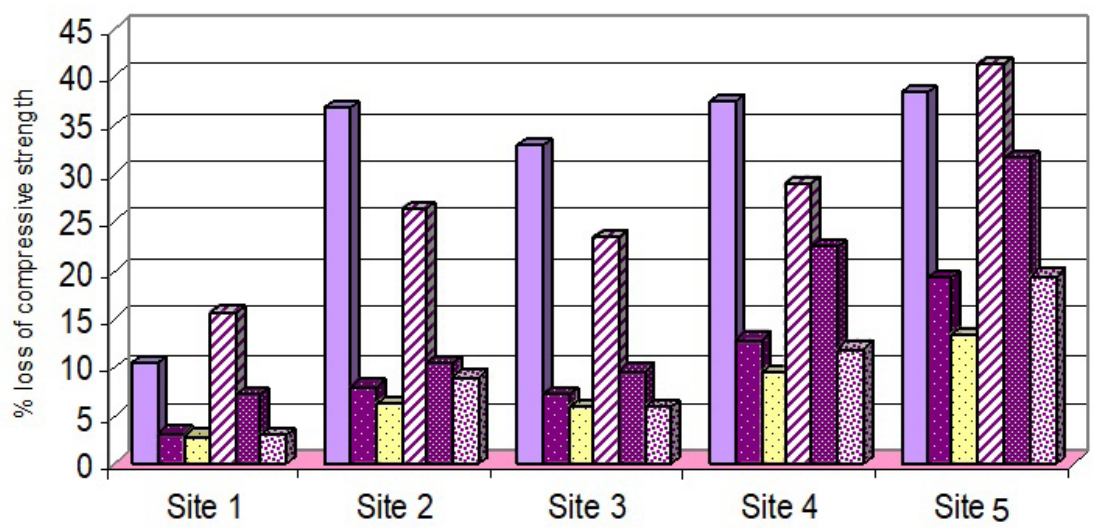

Figure 2 The percentage loss of compressive strength for different building units at various investigated sites in Cairo City after three years of exposure.

In case of sand-lime samples (Figure 1B), compared with the control samples of $22 \mathrm{~kg} / \mathrm{cm}^{2}$, the compressive strength at site 5 (industrial area) decreased to $181 \mathrm{~kg} / \mathrm{cm}^{2}$, which represents a loss of $19.2 \%$. The deterioration of sand-lime samples exposed at industrial area is six times higher than that exposed at residential area with low population density (site 1 ) and about 2.5 times higher than the deterioration at residential areas of moderate population density (sites 2,3). The deterioration of neat cement samples exposed to the industrial atmosphere (site 5) resulted in decrease in compressive strength from $1338 \mathrm{~kg} / \mathrm{cm} 2$ for the control samples to $1158 \mathrm{~kg} / \mathrm{cm}^{2}$ (Figure 1C). In other words, the compressive strength decreased at this site by $13.45 \%$ after three years of exposure compared with strength losses of $2.86 \%, 6.15 \%, 5.85 \%$ and $9.58 \%$ at sites 12,3 and 4 , respectively (Figure 2). For cement block samples (Figure 1D), the compressive strength of the exposed samples at the industrial district (site 5) decreased from $261 \mathrm{~kg} / \mathrm{cm} 2$ to $153 \mathrm{~kg} / \mathrm{cm}^{2}$. This means that $41.38 \%$ of the strength of cement block samples was lost after three years of exposure. This loss is about $1.5-3$ times higher than that found at the other residential areas. Compressive strength of gypsum samples show maximum decrease (from $78 \mathrm{~kg} / \mathrm{cm}^{2}$ to $53 \mathrm{~kg} / \mathrm{cm}^{2}$ ) after three years of exposure at site 5 (Figure 1E). The deterioration of gypsum samples at the industrial area is about three times higher than those at the residential areas. Figure $1 \mathrm{~F}$ shows that the magnitude of the deterioration of LECA samples exposed at different sites in Cairo atmosphere are approximately similar to that of the sand-lime samples. Figure 2 also indicates that limestone and cement blocks demonstrate higher strength losses than the other investigated materials. However, neat cement samples show lower losses in compressive strength followed by LECA and sand-lime samples. It can be concluded that the severity of the stone samples degradation in Cairo atmosphere after three years of exposure can be arranged as follows:

\section{Limestone $\approx$ cement block $>$ gypsum $>$ sand-lime $>$ LECA > neat cement}

Figure 3 illustrates the percentage compressive strength losses of limestone samples exposed at the chosen sites as a function of exposure times. The figure shows that the percentage loss of strength was fast during the first year and tends to be less progressive through the second and third year at all the sites of measurement. This behavior clearly indicated at site 5 (industrial area). This can be attributed to the higher concentrations of air pollutants mainly $\mathrm{SO}_{2}$ and sulfates, which can readily react with limestone forming gypsum. Due to the lack of rain in Egypt, these layers of gypsum can accumulate on the surfaces of stones forming crusts, which hinder further fast reactions. The percentage strength losses of different samples as a function of the time of exposure at the industrial area (site 5) are given in Figure 4. Figure 4 shows that, the behavior of the strength losses for the different samples can be categorized into different groups. The first group includes limestone and gypsum, where the strength loss increased at a fast rate through the first year and the rate declined through the second and third years. The second group includes cement blocks, sand-lime and neat cement, where the compressive losses rose steadily with the time of exposure. The third group includes LECA samples, where the strength losses increased steadily through the first two years and fastly through the third year. 


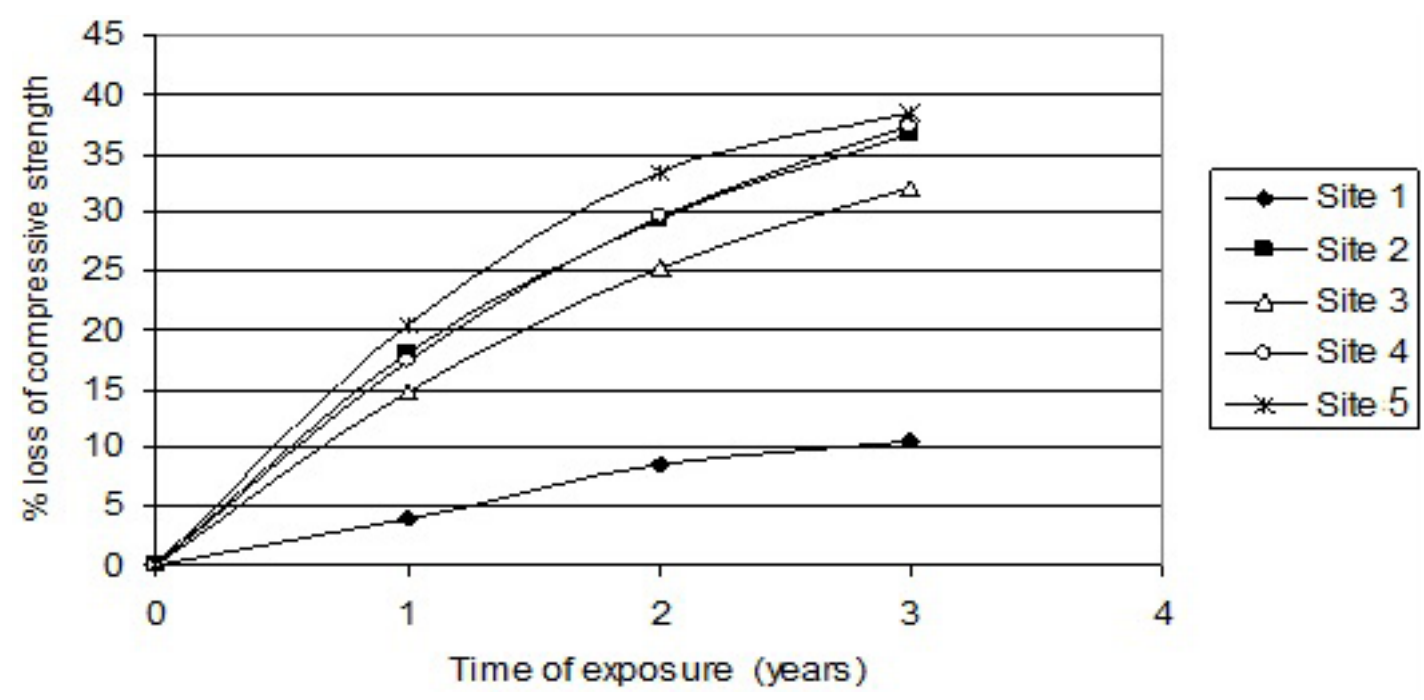

Figure 3 Loss of compressive strength of limestone samples exposure at various sites as a function of the time of exposure.

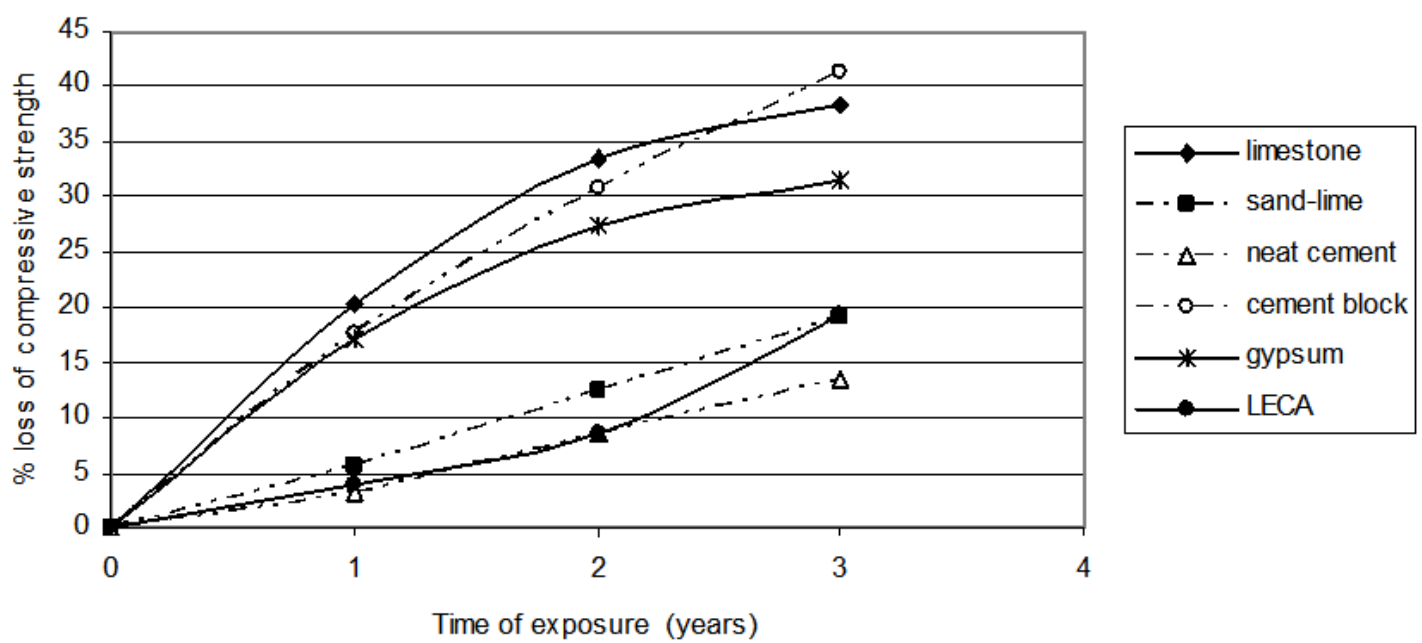

Figure 4 The strength losses of different building unit samples exposed at the industrial area (site 5) as a function of the exposure time.

$\mathrm{SO}_{2}$ doses (dose $=$ concentration $\mathrm{x}$ time) were calculated for the various periods of exposure at the different sites of investigation and correlated with the compressive strength losses of the exposed limestone samples. A positive correlation coefficient $(\mathrm{r}=0.71)$ was obtained, this means that the stone deterioration in the atmosphere becomes far more serious if the atmosphere contains sulfur dioxide. However, an important degradation mechanism in $\mathrm{SO}_{2}$ polluted environment is therefore the conversion to gypsum followed by dissolution. This result is confirmed by. ${ }^{1,27-30}$ Furthermore, Sabbioni ${ }^{2}$ $\&$ Vallero $^{3}$ reported that $\mathrm{SO} 2$ is for a long time considered to be the main corrosive pollutant on materials. Moreover, ${ }^{8-10}$ reported that chemical reaction on stone surface continues at all sulfur dioxide concentrations. He added that the oxidation of the $\mathrm{SO}_{2}$ aqueous phase is the key step in the formation of gypsum on the surface of the limestone. However, sulfur dioxide and moisture react with limestone $\left(\mathrm{CaCO}_{3}\right)$ to form calcium sulfate $\left(\mathrm{CaSO}_{4}\right)$ and gypsum $\left(\mathrm{CaSO}_{4} \cdot 2 \mathrm{H}_{2} \mathrm{O}\right)$ (as in equations $1 \mathrm{~A}$ and $1 \mathrm{~B}):{ }^{21-23}$

$$
\begin{aligned}
& \mathrm{CaCO}_{3}+\mathrm{H}_{2} \mathrm{SO}_{4} \rightarrow \mathrm{CaSO}_{4}+\mathrm{H}_{2} \mathrm{O}+\mathrm{CO}_{2} \text { (Eq. 1A) } \\
& \mathrm{CaCO}_{3}+\mathrm{SO}_{2}+2 \mathrm{H}_{2} \mathrm{O} \text { (vapour) } \rightarrow \mathrm{CaSO}_{4} \cdot 2 \mathrm{H}_{2} \mathrm{O}+\mathrm{CO}_{2} \text { (Eq. 1B) }
\end{aligned}
$$

These two sulfates are fairly soluble in water, causing deterioration in stones. The soluble calcium sulfates can penetrate into the pores of the limestone and recrystallize and expand, causing further deterioration. There is evidence also that damage occurs due to synergistic effect of sulfur dioxide and nitrogen oxides in Cairo atmosphere. Although, ${ }^{31-33}$ found that oxidation by $\mathrm{SO}_{2}$ is more significant than that by $\mathrm{NO}$ or $\mathrm{NO}_{2}$, in moist films on calcareous building stone, a good positive correlation ( $\mathrm{of} r=0.74$ ) found between the strength loss of limestone samples exposed in Cairo atmosphere and nitrogen dioxide dose for the various sites of measurements. Compressive strength loss of limestone samples is also correlated with the chemical constituents of deposited and suspended particulate matters (Table 2). The data of this table clearly indicate a positive correlation coefficient found with the chemical constituents of suspended and deposited particles, especially with suspended sulfates reaching 0.84 . However, sulfates can attack carbonate rocks in a dual way, either by direct dissolution due to the acidic conditions or by the conversion to the more soluble sulfites and sulfates. These results confirm the major role of acid deposition in the deterioration of the exposed limestone samples. Consequently, it may be concluded that the compressive strength loss of limestone and the continuation of this loss through the periods of the study were highly influenced by the pollution load with reference to sulfate, helped with chloride and nitrate concentrations in the atmospheres of the sites under investigation. This finding is in accordance with that of. ${ }^{1-3,11,23,34}$ 
Table 2 Correlation coefficient between compressive strength losses of limestone samples and the chemical constituents of deposited and suspended particulate matters at the investigated sites

\begin{tabular}{llll}
\hline Chemical constituents & Sulfates & Chlorides & Nitrates \\
\hline Deposited particles & 0.72 & 0.74 & 0.57 \\
Suspended particulates & 0.84 & 0.63 & 0.67 \\
\hline
\end{tabular}

\section{Mineralogical composition (X-ray diffraction)}

The mineralogical compositions of the building stone films taken from the surface crust of the control samples and after exposure for three years were examined at residential and industrial sites in Cairo City by X-ray diffraction and the obtained traces illustrated in Figure 5 - Figure 10.

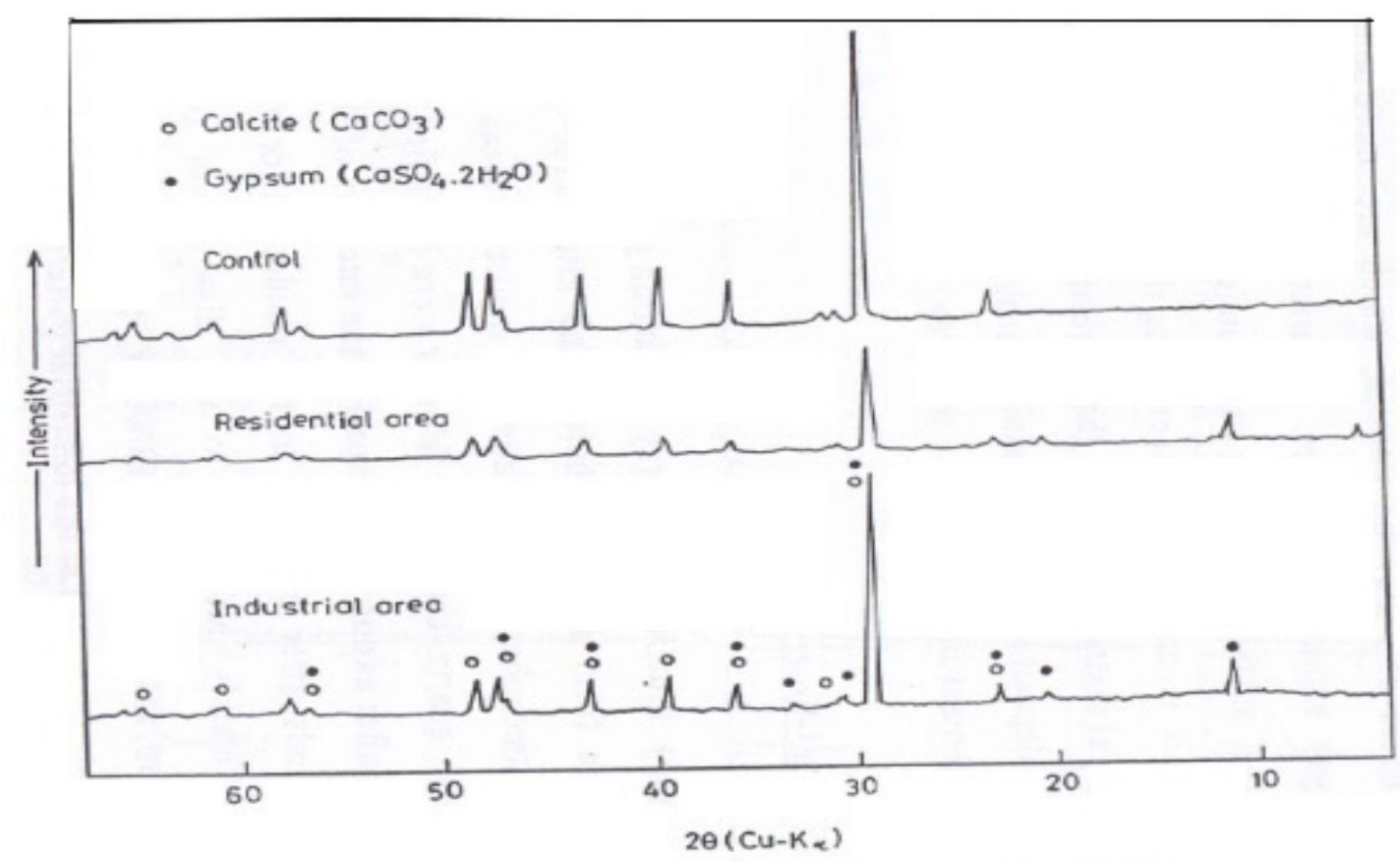

Figure 5 X-ray diffraction patterns of Limestone samples before and after exposure for three years at industrial and residential areas.

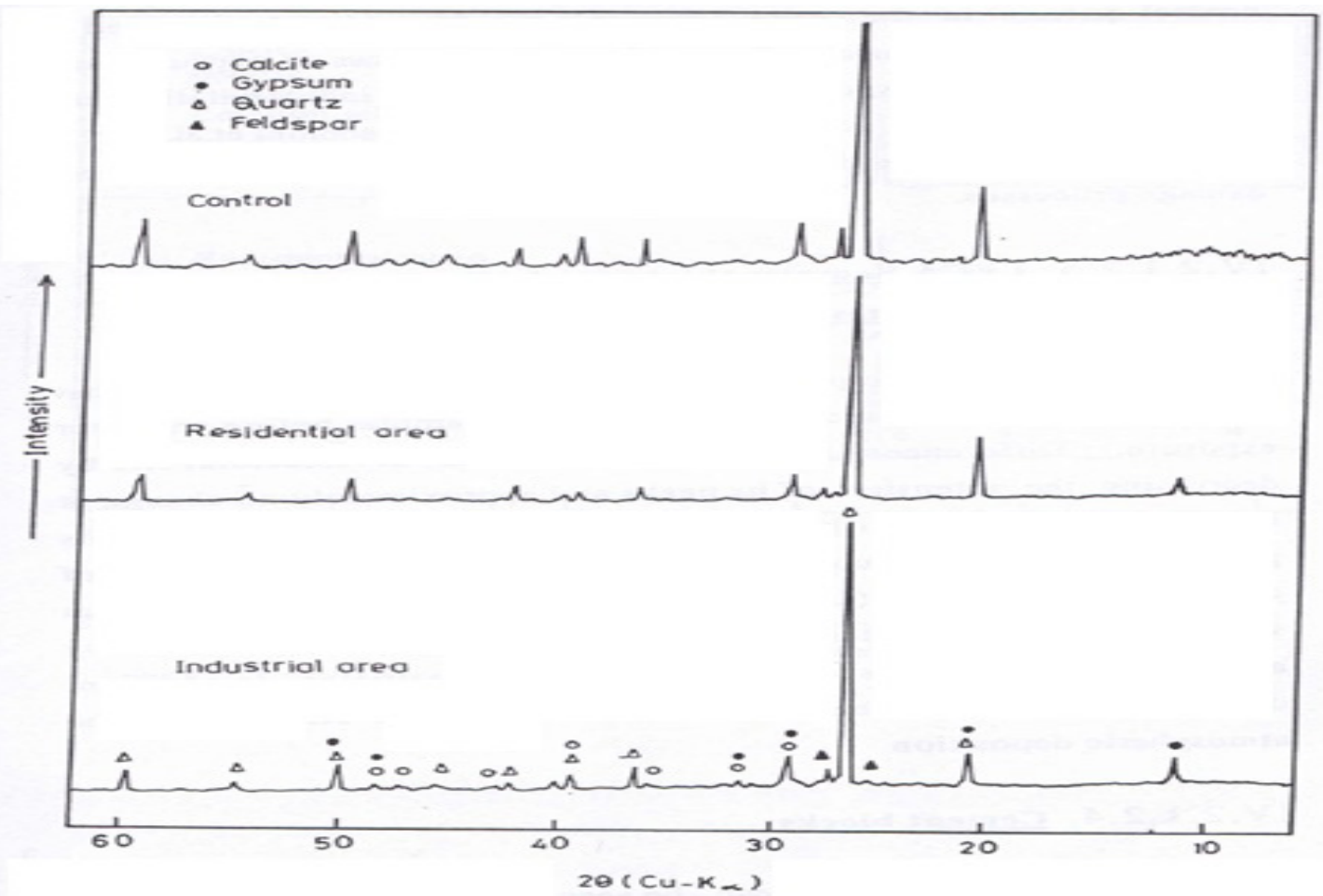

Figure 6 X-ray diffraction patterns of Sand-lime samples before and after exposure for three years at industrial and residential areas. 


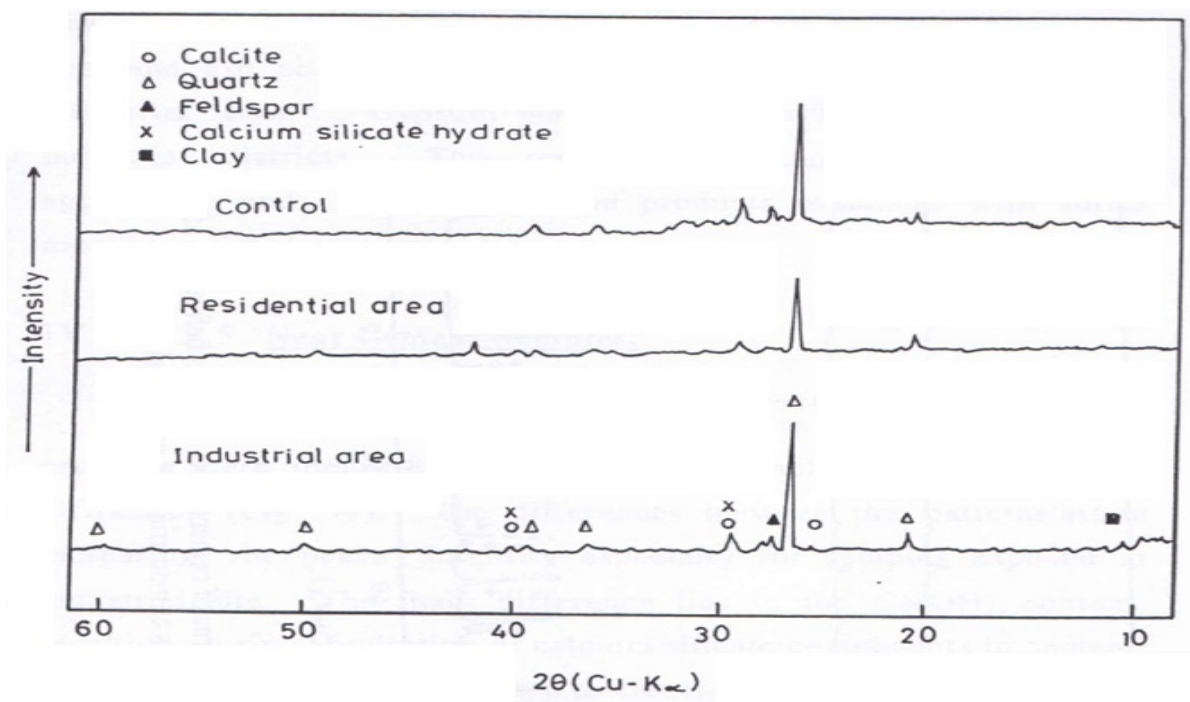

Figure 7 X-ray diffraction patterns of LECA samples before and after exposure for three years at industrial and residential areas.

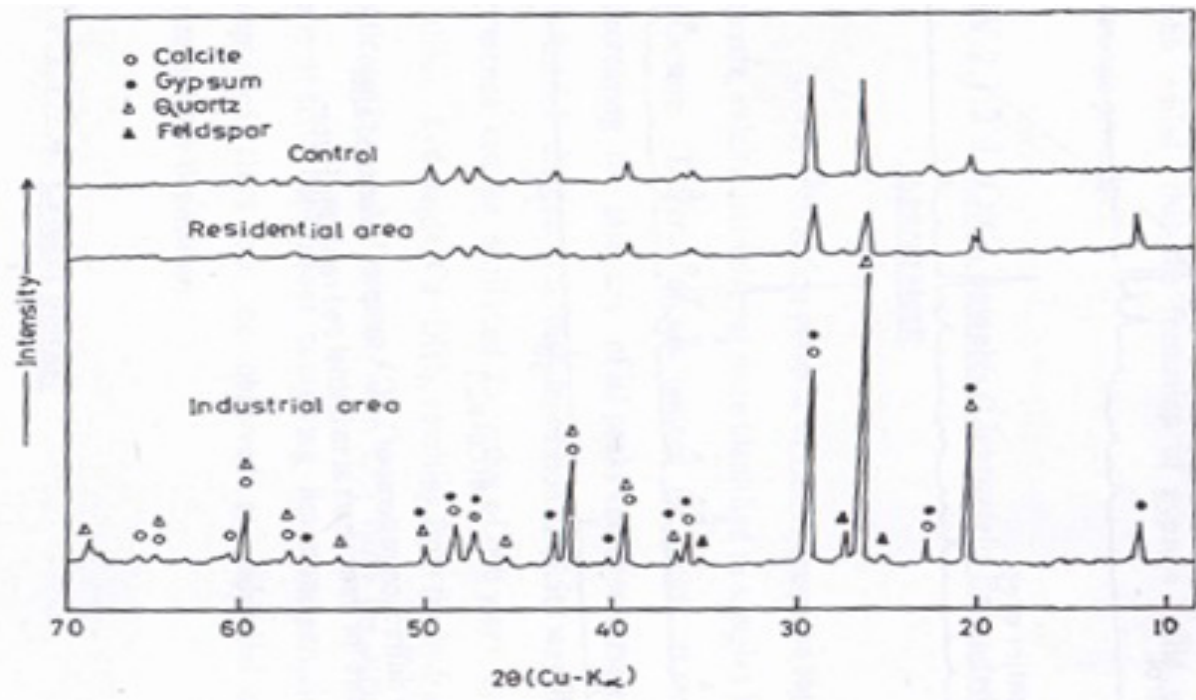

Figure 8 X-ray diffraction patterns of Cement blocks samples before and after exposure for three years at industrial and residential areas.

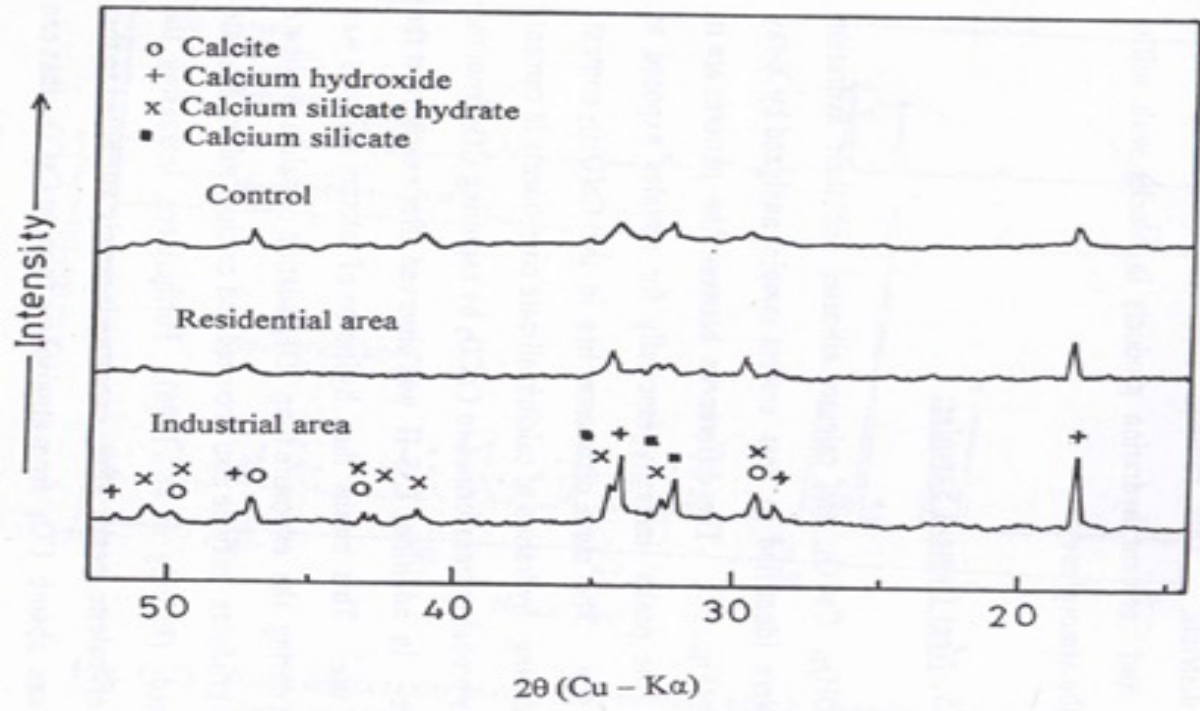

Figure 9 X-ray diffraction patterns of Neat cement samples before and after exposure for three years at industrial and residential areas. 


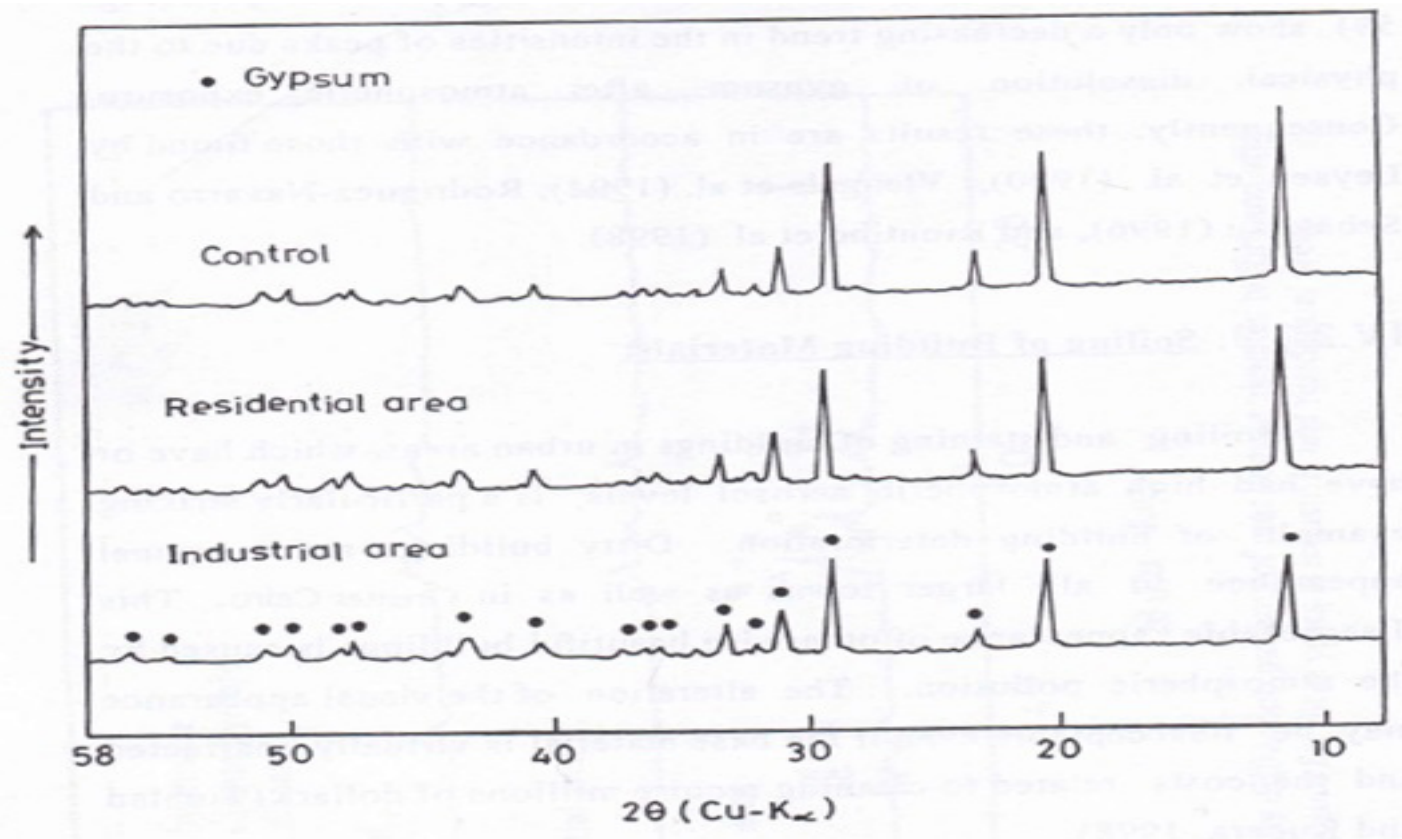

Figure 10 X-ray diffraction patterns of Industrial Gypsum samples before and after exposure for three years at industrial and residential areas.

\section{Limestone}

In the control, residential, and industrial patterns Figure 5, calcite $\left(\mathrm{CaCO}_{3}\right)$ was identified as the main component. After three years of exposure, the main difference lies in the identification of gypsum, resulting from the reaction of $\mathrm{CaCO}_{3}$ with sulfur dioxide in the atmosphere that measured in high concentration at the investigated sites especially at the industrial site. Similar findings are reported by ${ }^{35-39}$ Moreover, ${ }^{1-3}$ reported that gypsum $\left(\mathrm{CaSO}_{4} \cdot 2 \mathrm{H}_{2} \mathrm{O}\right)$ is a secondary mineral formed from calcite in the presence of sulfate in the atmospheric environment. From Figure 5, it can be also noticed the decreasing trend of the peaks intensity after exposure owing to the conversion of calcite to calcium sulfates and may be nitrates, which are more soluble. During prolonged exposure, however, a variety of products may be deposited on the surfaces including compounds originating from the atmosphere. This is confirmed by the increase in the intensity of calcite peaks at industrial district more than at residential district due to increasing the deposited dust containing probably limestone dust especially from cement industry nearby this area.

\section{Sand-lime}

In general, quartz, calcite and feldspar were identified in sandlime before and after exposure Figure 6. Decreasing the intensity of the peaks of these compounds after exposure to the residential or industrial atmosphere is mainly attributed to the dissociation of these compounds due to the exposure. However, the intensity of these peaks is relatively increased at the industrial pattern more than those of the residential one. This is possibly attributed to the dust deposition on the surface of the samples. The chemical effect of exposure is the dissociation of calcium silicate hydrate represented by the broad bands, found in the control pattern in the region between 8-1220, which disappeared at residential and industrial patterns. In addition, traces of gypsum were found at samples exposed at both residential and industrial districts. These results are in accordance with those of..$^{40-43}$

\section{LECA samples (Lightweight expanded clay aggregates)}

X-ray diffraction patterns of LECA samples (Figure 7) show that quartz, calcite and feldspar were identified in samples before and after exposure. Differences are noticed for quartz at residential site by decreasing the intensity of its peaks and approximately no change at industrial site due to further deposition. Calcite was also detected; its presence can be attributed to either of two ways: by the reaction of calcium hydroxide, $\mathrm{Ca}(\mathrm{OH}) 2$, resulting from the hydration of calcium silicate in cement content, with $\mathrm{CO}_{2}$ from the atmosphere, or by atmospheric depositions containing limestone particles. In addition, deposited clays can be observed at industrial site due to the atmospheric deposition.

\section{Cement blocks}

From Figure 8, quartz and calcite only were identified before the exposure. After three years of exposure, degradation of these compounds were occurred at residential site as confirmed by decreasing the intensity of their peaks, while an increasing trend in such intensities was observed at industrial site owing to dust deposition.

Feldspar $\left(\mathrm{NaAlSi}_{3} \mathrm{O}_{8}\right)$, which is one of dust and ash constituent, was identified in samples exposed in the industrial area. Gypsum was identified at both residential and industrial districts which resulted from the reaction of calcite aggregates and cement hydration products in blocks with sulfur dioxide in the atmosphere.

\section{Neat cement samples}

$\mathrm{Ca}(\mathrm{OH})_{2}, \mathrm{CaCO}_{3}$, and calcium silicates and their hydration products were identified in neat cement samples (Fig. 9). The differences between the patterns are in increasing the peaks intensity especially for samples exposed at industrial site. The main difference lies in the $\mathrm{Ca}(\mathrm{OH})_{2}$, content, resulting during hydration of calcium silicate components in cement. $\mathrm{Ca}(\mathrm{OH})_{2}$ is probably transformed to 
$\mathrm{CaCO}_{3}$ by capturing $\mathrm{CO}_{2}$ from the atmosphere. In addition, $\mathrm{C}-\mathrm{S}-\mathrm{H}$ was observed after exposure at the industrial site. This means that hydration of calcium silicates was continued during the exposure time. Degradation of calcium silicate hydration products may be also occurred and calcium sulfate hydrate was formed. ${ }^{44,45}$ Furthermore, increasing the intensity of calcite peaks after exposure is mainly attributed to that $\mathrm{Ca}(\mathrm{OH}) 2$ can absorb $\mathrm{CO}_{2}$ from atmosphere forming $\mathrm{CaCO}_{3}$, that can deposited into the surface pores of the samples in addition to the deposited particles. This may explain the lower decrease in compressive strength that measured in the present study for neat cement samples when exposed to the atmosphere.

\section{Industrial gypsum samples}

Figure 10 shows only a decreasing trend in the intensities of peaks due to the physical dissolution of gypsum after atmospheric exposure. Consequently, these results are in accordance with those found by. ${ }^{46-53}$

\section{Conclusion}

It can be concluded that; the deterioration in compressive strength of building materials, exposed to Cairo city through the period of study, was highly related to the atmospheric pollution load with reference to $\mathrm{SO}_{2}$, sulfate, chloride and nitrate concentrations and the severity of the reaction of pollutants on the surface of the stone samples. The higher deterioration of the building materials was recorded for samples exposed at the industrial areas compared to those exposed to the other residential districts. Limestone and cement blocks are more sensitive to air pollutants and have poor resistance to atmospheric deterioration than the other investigated stones, whereas neat cement, LECA samples, and sand-lime have much better weathering resistance. The severity of the stone samples degradation in Cairo atmosphere after three years of exposure can be discerningly arranged as follows:

Limestone $\sim$ cement block $>$ gypsum $>$ sand-lime $>$ LECA $>$ neat cement

The sensitivity of different building materials to the atmospheric pollution can give useful information for the selection of the suitable types for construction purposes, which can resist the prevailing atmospheric conditions in Egypt. The mineralogical composition (X-ray diffraction) of the product films of the exposed building materials showed the formation of gypsum and hydrated calcium silicate components in the building materials and cement content.

\section{Acknowledgments}

None.

\section{Conflicts of interest}

The authors declare that there is no conflict of interest.

\section{References}

1. Tidblad J, Kucera V. Materials Damage. In VI Impacts of Urban Air Pollution. Chapter 19, Dordrecht, Netherland. 1998:343-361.

2. Sabbioni C. Chapter: MECHANISMS OF AIR POLLUTION DAMAGE TO STONE. In book: The Effects of Air Pollution on the Built Environment. 2003.

3. Vallero DA. Fundamentals of Air Pollution. 4th edn. Duke University Durham, North Carolina, USA. Academic Press is an imprint of Elsevier; 2008.

4. Godish, T. Air Quality. 3rd edn. New York, USA. Lewis Publishers; 1997.
5. Hinriksen JF. Proceeding of the 3rd International Symposium, 189-194. Venezia. 1994.

6. Grossia, CM, Murray M. Characteristics of carbonate building stones that influence the dry deposition of acidic gases. Construction and Building Materials. 1999;13:101-108.

7. Taylor AR, Ocaña-González JA, Pérez-Bernal JL. An Accelerated Chemical Weathering Assay: Sulfation of Acinipo Limestone in a Humid and $\mathrm{SO}_{2}$ Rich Environment. Journal of Laboratory Chemical Education. 2018;6(4):133-139.

8. Massey SW. The effects of ozone and NOx on the deterioration of calcareous stone. The Sci Total Environ. 1999;227:109-121.

9. De Kock T, Van Stappen J. Laminar gypsum crust on Lede stone: microspatial characterization and laboratory acid weathering. Talanta. 2017;162:193-202.

10. Farkas O, Siegesmund S, Licha T, et al. Geochemical and mineralogical composition of black weathering crusts on limestones from seven different European countries. Environmental Earth Sciences. 2018;77:211.

11. Wark K, Warner CF. Air pollution, its origin and control. 2nd edn. NY. Harper and Row Publishers; 1981

12. Kenneth W, Cecil FW, Davis WT. Air pollution, its origin and control. 3rd edn. Published by Menlo Park CA: Addison-Wesley. 1998.

13. Kumar S, Rao K. Strength loss in concrete due to varying sulfate exposures. Cement and Concrete Research. 1995;25(1):57-62.

14. Zhou Y, Tian H, Sui L, et al. Strength Deterioration of Concrete in Sulfate Environment: An Experimental Study and Theoretical Modeling. Advances in Materials Science and Engineering. 2015:13.

15. Harrison RMS, Perry R. Handbook of Air Pollution Analysis. 2nd edn. London, New York, Chapman and Hall, NY. 1986.

16. Stern AC. Air Pollution. 3rd edn. New York. Academic Press Inc; 1986.

17. JIS (Japanese Industrial Standards). General Rule for Test Methods of Reagents. Tokyo, Japan. Japanese Industrial Standards Committee. 1992.

18. Mohammed AMF. Hazardous air pollutants emitted from Fossil-Fuel-fired Power Plants and their impacts on Greater Cairo air quality. Chemistry Department, Egypt. Ain Shams University; 2012.

19. Colton T. Statistics in Medicine. Lille, Boston. Brown and Company; 1974. p. 16-125.

20. Riffenburgh R. Statistics in Medicine. 3rd edn. Chapter 5. Descriptive Statistics. 2021

21. Nord AG, Svardth A, Tronner K. Air pollution levels reflected in deposition on building stone. Atmos Environ. 1994;28(16): 2615-2622.

22. Bityukova L. Air Pollution Effect on the Decay of Carbonate Building Stones in Old Town of Tallinn. Water Air and Soil Pollution. 2006;172(1):239-271.

23. Graue B, Siegesmund S, Oyhantcabal P, et al. The effect of air pollution on stone decay: the decay of the Drachenfels trachyte in industrial, urban, and rural environments - a case study of the Cologne, Altenberg and Xanten cathedrals. Environ Earth Sci. 2013;69:1095-1124.

24. Hutchinson AJ, Johnson JB, Thopson GE, et al. Stone degradation due to dry deposition of $\mathrm{HCl}$ and $\mathrm{SO} 2$ in a laboratory-based exposure chamber. Atmospheric Environment. 1992b;26A(15):2785-2793.

25. Olaru M, Aflori M, Simionescu B, et al. Effect of $\mathrm{SO}_{2}$ Dry Deposition on Porous Dolomitic Limestones. Materials. 2010;3:216-231.

26. Mahadam PD, Mane AV. Effect of simulated acidic rain concentrations on selected materials used in construction. Environmental Science An Indian Journal (ESAIJ). 2013;8(10). 
27. Arroyave C, Morcillo M. The effect of sulfur oxides in atmospheric corrosion of metals. Corros Sci. 1995;37:293-305.

28. Kilincceker G, Taze N, Galip H, et al. The effect of sulfur dioxide on iron, copper and brass. Anti-Corrosion Methods and Materials. 2011;5(1):412 .

29. Chen W, Hao L, Dong J, et al. Effect of sulphur dioxide on the corrosion of a low alloy steel in simulated coastal industrial atmosphere. Corrosion Science. 2014;83:155-163.

30. Diab AM, Elyamany HE, Abd Elmoaty AEM, et al. Prediction of concrete compressive strength due to long term sulfate attack using neural network Alexandria Engineering Journal. 2014;53(3):627-642.

31. Haneef SJ, Johnson JB, Dickinson C, et al. Effect of dry deposition of $\mathrm{NO}_{x}$ and $\mathrm{SO}_{2}$ gaseous pollutants on the degradation of calcareous building stones. Atmos. Environ. 1992;26A(16):2963-2974.

32. Allen GC, El-Turki A, Hallam KR, et al. Role of $\mathrm{NO}_{2}$ and $\mathrm{SO}_{2}$ in degradation of limestone. British Corrosion Journal. 2000:35(1):35-38.

33. Müller U. The mineralogical composition of sandstone and its effect on sulphur dioxide deposition. Materiales de Construcción. 2008;58 (289290):81-95.

34. Hutchinson AJ, Johnson JB, Thopson GE, et al. The role of fly-ash particulate material and oxide catalysts in stone degradation. Atmospheric Environment. 1992a;26A(15): 2795-2803.

35. Elfving P, Panas I, Linqvist O. Model study of the first steps in the deterioration of calcareous stone. III. Manganese and iron mediated sulfation of natural stone. Appl Surf Sci. 1994;78:373-384.

36. Torfs K, Vangrieken R. Effect of stone thickness on run-off water composition and derived damage functions in ambient exposure experiments. Atmos Environ. 1996;30(1):1-8.

37. Lazic V, Colao F, Fantoni R, et al. Spectroscopic Monitoring of the Laser Cleaning Applied to Ancient Marbles from Mediterranean Areas. In: Dickmann K, Fotakis C, editors. Lasers in the Conservation of Artworks. Springer Proceedings in Physics. Berlin, Heidelberg. Springer; 2005.

38. Siegesmund S, Snethlage R. Stone in Architecture. 4th edn. Chapter 4 Weathering and Deterioration. Springer-Verlag Berlin Heidelberg. 2011.

39. Eyssautier-Chuine S, Marin B, Thomachot-Schneider C, et al. Simulation of acid rain weathering effect on natural and artificial carbonate stones. Environ Earth Sci. 2016;75:748.

40. Sabbioni C, Zappia G, Gobbi G, et al. Deterioration of ancient and modern buildings materials due to environmental factors. Structural Repair and Maintenance of Historical Buildings III. 1993:235-242.

41. Korkanc M. Deterioration of different stones used in historical buildings within Nigde province, Cappadocia. Construction and Building Materials. 2013;48:789-803.

42. Maria-Margarita M. The deterioration mechanisms of building materials and innovative ways to conserve them Case study: the Medieval Town of Rhodes. Greece. Edinburgh College of Art, University of Edinburgh; 2014.
43. Almusaed A, Almssad A, Homod R, et al. Environmental Profile on Building Material Passports for Hot Climates. Sustainability. 2020;12:3720.

44. Elfving P, Panas I, Linqvist O. In situ IR study on the initial sulfation and carbonation of $\mathrm{Ca}(\mathrm{OH})_{2}$ and $\mathrm{CaO}$ by $\mathrm{SO} 2$ polluted air. Atmospheric Environment. 1996;30(23):4085-4089.

45. Ishizuka T, Kabashima H, Yamaguchi T, et al. Initial Step of Flue Gas Desulfurization An IR Study of the Reaction of $\mathrm{SO}_{2}$ with $\mathrm{NOx}$ on $\mathrm{CaO}$. Environmental Science and Technology. 2000;34(13):2799-2803.

46. Leysen L, Roekens E, Van Grieken R. Characterization of the weathering crust of various historical buildings in Belgium. Sci Total Environ. 1990;90:117-147.

47. Vleugels G, Forbe B, Dewolfs R, et al. Surface composition alteration of bare and treated limestone after ambient exposure. Sci Total Environ. 1994;151:59-69.

48. Rodriguez-Navarro CR, Sebastian E. Role of particulate matter for vehicle exhaust on porous building stones (limestone) sulfation. Sci Total Environ. 1996:178:79-91.

49. Riontino C, Sabbioni C, Ghedini N, et al. Evaluation of atmospheric deposition on historic buildings by combined thermal analysis and combustion techniques. Thermochimica Acta. 1998;321:215-222.

50. Simao J, Ruiz-Agudo E, Rodriguez-Navarro C. Effects of particulate matter from gasoline and diesel vehicle exhaust emissions on silicate stones sulfation. Atmospheric Environment. 2006;40:6905-6917.

51. Ozga I, Bonazza1A, Bernardi E, et al. Diagnosis of surface damage induced by air pollution on 20th-century concrete buildings. Atmospheric Environment. 2011;45:4986-4995.

52. Kock TD, Dewanckele J, Marijn B, et al. Multidisciplinary characterization of gypsum crust on lede stone (belgium). New York. 12th International Congress on the Deterioration and Conservation of Stone Columbia University; 2012.

53. Abdellah MY, Gelany AF, Mohamed AF, et al. Protection of Limestone Coated with Different Polymeric Materials. American Journal of Mechanical Engineering. 2017;5(2):51-57.

54. German Standard Method. DEV: Deutsche Einheitsver fahren zur WasserAbwasser und Schlammuntersuchung. Verlag Chemie, Weinheim. 1984.

55. Godish T. Air Quality. 5th edition. New York, USA. Lewis Publishers; 2015 .

56. Saleh IA. Air Quality and Effects of Air Pollutants on Materials of Different Structures in Cairo Atmosphere. Egypt. Ain Shams University; 2002 . 